Volume 6 No. 2, Desember 2019

P-ISSN: 2406-808X // E-ISSN: 2550-0686

https://journal.iainlangsa.ac.id/index.php/ikhtibar

https://doi.org/10.32505/ikhtibar.v6i2.608

\title{
MUTIARA TERPENDAM ( ANALISIS TEKS ) DALAM NOVEL BULAN TERBELAH DI LANGIT AMERIKA KARYA HANUM SALSABIELA RAIS DAN RANGGA ALMAHENDRA
}

\author{
Nani Endri Santi ${ }^{1}$. Khairunnisa ${ }^{2}$ \\ Institut Agama Islam Negeri Langsa \\ khairunnisakhairunnisa64@gmail.com
}

\begin{abstract}
Abstrak
Novel merupakan sebuah karya yang mengungkapkan seluruh episode perjalanan hidup tokoh-tokoh ceritanya. Pada era globalisasi ini bangsa Indonesia mengalami ketertinggalan dibandingan dengan negara lain dalam hal ilmu pengetahuan. Salah satu upaya untuk mendapatkan ilmu pengetahuan ialah dengan cara banyak membaca buku baik buku pelajaran maupun buku-buku novel. Membaca merupakan salah satu kegiatan menganalisis dan menginterpretasikan yang dilakukan oleh pembaca untuk memperoleh pesan atau nilai-nilai kehidupan dari sebuah buku. Namun kebanyakan masyarakat Indonesia sangat kurang berminat dalam membaca novel umum. Tujuan dari penelitian ini adalah untuk mengetahui Nilai-Nilai Pendidikan Islam Dalam Novel Bulan Terbelah Di Langit Amerika Karya Hanum Salsabiela Rais Dan Rangga Almahendra. Penelitian ini termasuk ke dalam jenis penelitian pustaka (library research) dan pendekatan deskriptif kualitatif dengan cara pengumpulan data yang merujuk kepada berbagai sumber lain yang relevan. Setelah data terkumpul, kemudian dianalisis dengan prinsip analisis isi (content analysis). Penelitian ini dapat disimpulkan bahwa Cerita Novel Bulan Terbelah diLangit Amerika mengandung nilai-nilai pendidikan Islam seperti nilai aqidah, nilai syari'ah, dan nilai akhlak yang dapat diambil manfaatnya khususnya dalam dunia pendidikan, menambah wawasan terhadap peristiwa sejarah yang terjadi dalam kehidupan si penulis tersebut, dan meningkatkan minat baca terhadap novel-novel islami dalam memahami pesan suatu karyasastra.
\end{abstract}

Kata Kunci: Nilai Pendidikan, Islam, Novel

\section{Pendahuluan}

Pendidikan ialah proses kebaikan, penguatan, dan penyempurnaan terhadap semua kemampuan dan potensi manusia. Pendidikan juga dapat diartikan sebagai suatu ikhtiar manusia untuk membina kepribadiannya sesuai dengan nilai-nilai dan kebudayaan yang ada dalam masyarakat.

Pada dasarnya, nilai-nilai pendidikan Islam tidak hanya terdapat dalam Alqur'an dan Hadits saja melainkan melalui karya sastra manusia. Pada hakikatnya kita sebagai manusia memiliki karya sastra, tetapi karya sastra yang kita buat tidak dengan menggunakan aturan-aturan yang ada dalam pembuatan karya sastra itu sendiri. Karya yang memiliki definisi hasil jerih payah merupakan buatan diri kita sendiri dan tanpa hasil copy dari orang lain. Dan sastra juga adalah pemanis indahnya bahasa untuk membuat suatu karya. Novel merupakan sebuah karya yang mengungkapkan seluruh 
episode perjalanan hidup tokoh-tokoh ceritanya. Karya sastra apapun yang ditulis oleh manusia harus mengandung nilai-nilai yang penting dan berguna bagi kemanusiaan.

Pada era globalisasi ini Bangsa Indonesia mengalami ketertinggalan dibandingkan dengan negara lain dalam hal ilmu pengetahuan. Pada zaman yang sudah maju ini dibutuhkan pengetahuan yang luas, sehingga mampu bersaing dan berinovasi dalam ilmu pengetahuan. Salah satu upaya untuk mendapatkan ilmu pengetahuan ialah dengan cara banyak membaca buku baik buku pelajaran maupun buku-buku novel umum.

Membaca merupakan salah satu kegiatan menganalisis dan menginterpretasikan yang dilakukan oleh pembaca untuk memperoleh pesan dari penulis dalam media tulisan. Dengan mudahnya kita bisa membaca setiap saat. Setiap daerah juga memiliki perpustakaan yang dapat memudahkan masyarakat khususnya pelajar maupun mahasiswa untuk memperoleh buku-buku pelajaran.

Namun kebanyakan masyarakat Indonesia sangat kurang berminat dalam membaca buku. Berdasarkan pernyataan menurut UNESCO, minat baca masyarakat Indonesia sangat memprihatinkan, hanya $0,001 \%$. Artinya, dari 1000 orang Indonesia, cuma 1 orang yang rajin membaca. Riset berbeda yang berjudul "Most Littered Nation In the World" yang dilakukan oleh Central Connecticut State Univesity pada Maret 2016 lalu, Indonesia dinyatakan menduduki peringkat ke-60 dari 61 negara soal minat membaca. Ini artinya, Indonesia persis berada di bawah Thailand (59) dan di atas Bostwana (61). Padahal, dari segi penilaian infrastuktur untuk mendukung membaca peringkat Indonesia berada di atas negara-negara Eropa. ${ }^{1}$

Ironinya, angka ini berbanding terbalik dengan jumlah pengguna internet yang mencapai separuh dari total populasi penduduk Indonesia atau sekitar Rp. 132,7 juta. Bahkan data yang dihimpun statista.com pada January 2018, disebutkan bahwa 44 persen populasi masyarakat Indonesia mengambil foto dan video menggunakan ponsel mereka.

Rendahnya minat baca di Indonesia, menurut Collin McElwee, Co-Founder Worldreader, salah satunya dipengaruhi oleh sulitnya akses terhadap buku. Tak hanya itu, Collin juga mengatakan bahwa gempuran inovasi di bidang teknologi membuat masyarakat terutama milenial lebih senang menatap layar gawai dibandingkan membaca buku. ${ }^{2}$

Seperti halnya novel Bulan Terbelah Di Langit Amerika yang ditulisoleh Hanum Salsabiela Rais dan Rangga Almahendra. Novel ini sangat menarik dari segi judul, cover, tokoh-tokoh, dan alur ceritanya. Novel ini juga sangat cocok bagi pelajar, mahasiswa, sampai kalangan orang dewasa. Penggunaan novel sebagai media tambahan untuk memperoleh imu pengetahuan sangat efektif, sehingga kita dapat mengetahui bahkan menambah wawasan berdasarkan cerita yang terdapat di dalam novel tersebut.

Ada banyak cara menyampaikan nilai-nilai pendidikan Islam, adalah salah satunya yang digunakan oleh Hanum Salsabiela Rais dan Rangga Almahendra melalui karya sastranya berupa novel yang berjudul Bulan Terbelah Di LangitAmerika. Dimana di dalam novel ini terdapat banyak hikmah atau pesan pendidikan khususnya nilai-nilaipendidikan Islam.

${ }^{1}$ http://edukasi.kompas.com/read/2016/08/29/07175131/minat.baca.indonesia.ada.di.urutan.ke60.dunia diakses pada tanggal 26 Desember 2018, pukul 14.05 WIB.

${ }^{2}$ https://www.suara.com/lifestyle/2018/02/21/173000/miris-minat-baca-masyarakat-indonesiahanya-001-persen, diakses pada tanggal 26 Desember 2018, pukul 14.05 WIB. 
Dengan demikian, novel bukan hanya diperuntukkan dibaca untuk hiburan semata, akan tetapi dari cerita novel dapat diambil makna yang penting bagi kehidupan pembaca khususnya yang mengandung nilai-nilai pendidikan Islam yang terdapat dalam novel tersebut.

Dari latar belakang yang telah dipaparkan di atas, maka pada penelitian ini diusulkan"MUTIARA TERPENDAM (ANALISIS TEKS) DALAM NOVEL BULAN TERBELAH DI LANGIT AMERIKA KARYA HANUM SALSABIELA RAIS DAN RANGGA ALMAHENDRA".

\section{Rumusan Maslah}

Berdasarkan latar belakang permasalahan diatas, maka yang menjadi rumusan masalah dalam penelitian ini ialah: Apa sajakah Nilai-Nilai Pendidikan Islam Dalam Novel Bulan Terbelah Di Langit Amerika Karya Hanum Salsabiela Rais Dan Rangga Almahendra?

\section{Tujuan}

Tujuan penelitian ini adalah untuk mengetahui Nilai-Nilai Pendidikan Islam Dalam Novel Bulan Terbelah Di Langit Amerika Karya Hanum Salsabiela Rais Dan Rangga Almahendra.

\section{Metode Penelitian}

Ditinjau dari objek kajian dan tempatnya, penelitian ini termasuk kategori penelitian pustaka (library research). Adapun yang dimaksud penelitian pustaka adalah sesuatu penelitian yang dilakukan di ruang perpusakaan untuk menghimpun dan menganalisis data yang bersumber dari perpustakaan, baik berupa buku-buku, periodikal-periodikal, seperti majalah-majalah ilmiah yang diterbitkan secara berkala, kisah-kisah sejarah, dokumen-dokumen dan materi perpustakaan lainnya, yang dapat dijadikan sumber rujukan untuk menyusun suatu laporan ilmiah. ${ }^{3}$

Data yang penulis peroleh dalam penelitian ini dari berbagai sumber. Data tersebut diklasifikasikan menjadi data primer dan data sekunder. Data primer adalah data yang berkaitan dengan objek penelitian, dalam hal ini adalah novel Bulan Terbelah Di Langit Amerika yang diterbitkan oleh Gramedia Pustaka pada tahun 2014, dengan jumlah 349 halaman dan terdapat 72 jumlah sub bagian cerita, sedangkan data sekunder adalah data pendukung yang membantu analisis dalam penelitian ini yaitu buku-buku tentang sastra dan buku-buku agama Islam yang relevan dan buku-buku yang terdapat dalam aplikasi perpustakaan online.

Teknik pengumpulan data yang dilakukan dalam penelitian ini yaitu dengan riset kepustakaan yang yang memanfaatkan teori-teori, pendapat para ahli, dan dalildalil dari Al-qur'an dan Hadits serta bacaan lainnya yang relevan dengan penelitian yang penulis lakukan.

Penelitian di samping perlu menggunakan metode yang tepat, juga perlu memilih teknik dan alat pengumpulan data yang relevan. ${ }^{4}$ Dalam hal ini, data yang

\footnotetext{
${ }^{3}$ Abdurrahmat Fathoni, Metodologi Penelitian \& Teknik Penyusunan Skripsi, (Jakarta :Rineka Cipta, 2006), hal. 95.

${ }^{4}$ Nurul Zuriah, Metodologi Penelitian Sosial Dan Pendidikan Teori Dan Aplikasi, (Jakarta: Bumi Aksara, 2007), hal. 171
} 
dikumpulkan berupa kata-kata, gambar, dan bukan angka-angka. Dengan demikian laporan penelitian akan berisi kutipan-kutipan data untuk memberi gambaran penyajian laporan tersebut. ${ }^{5}$ Teknik pengumpulan data yang dilakukan dalam penelitian ini dengan dokumentasi peneliti menghimpun data dari berbagai sumber seperti media visual misalnya buku atau novel.

Penelitian yang dilakukan terhadap data yang diperoleh dari berbagai literatur biasa dikenal dengan penelitian analisis dokumen atau analisis isi ( content analysis). ${ }^{6}$ Analisis isi (content analysis) adalah teknik penelitian untuk membuat inferensi-inferensi yang dapat ditiru (repicable), dan shahih data dengan memerhatikan konteksnya. Analisis isi berhubungan dengan komunkasi atau isi komunikasi. Logika dasar dalam komunikasi yaitu bahwa setiap komunikasi selalu berisi pesan dalam sinyal komunikasinya itu, baik berupa verbal maupun nonverbal. ${ }^{7}$

Content analysis ini dapat dilakukan dengan beberapa tahapan sebagai berikut:

\section{Deskripsi}

Metode ini merupakan pemaparan dan penafsiran terhadap data yang telah ada, sehingga dalam pemaparan atau penafsiran tersebut baik berupa objek-objek, kasuskasus maupun situasi yang dialami.

\section{Interpretasi}

Metode ini dimaksudkan untuk memahami suatu karya berikut dengan penjelasanpenjelasan terkait nilai-nilai pendidikan islam dalam novel Bulan Terbelah Di Langit Amerika karya Hanum Salsabiela Rais Dan Rangga Almahendra.

\section{Analisis}

Metode ini menguraikan suatu pokok atas berbagai bagainnya dan penelaahan bagian itu sendiri serta hubungan antar bagian untuk memperoleh pengertian yang tepat dan pemahaman arti keseluruhan. Sehingga metode ini digunakan untuk menguraikan nilai-nilai pendidikan Islam dalam novel Bulan Terbelah Di Langit Amerika.

Memberi interpretasi terhadap teks dalam penelitian kualitatif, analisis isi ditekankan pada bagaimana peneliti melihat keajekan isi komunikasi secara kualitatif, pada bagaimana peneliti memaknakan isi komunikasi, membaca simbol-simbol, memaknakan isi interaksi simbolis yang terjadi dalam komunikasi.

Kuntowijoyo dalam hal ini mengatakan bahwa simbol tidak dapat dipisahkan dari struktur sosial, gaya hidup, sosialisasi, agama, mobilitas sosial, organisasi kenegaraan dan seluruh perilaku sosial. Itulah sebabnya tanpa mempelajari sistem simbol suatu masyarakat, maka sulitlah mempelajari perilaku atau kebudayaan suatu masyarakat dengan baik, dan untuk menangkap yang disebut makna kebudayaan perlulah mengetahui terlebih dahulu cara menafsir simbol-simbol yang setiap saat dan tempat dipergunakan orang dalam kehidupan umum. ${ }^{8}$ Oleh karena itu, pemahaman dasar terhadap kultur di mna komunikasi itu terjadi sangat penting. Kultur ini menjadi muara yang luas terhadap berbagai macam bentuk komunikasi di masyarakat.

Tujuan dari analisis isi adalah mendeskripsikan isi yang tampak dari komunikasi. Langkah penggunaan analisis isi berkaitan dengan objek penelitian yang menjadi sasaran. Kalau objek penelitian berhubungan dengan data-data verbal, maka perlu disebutkan tempat, tanggal, dan alat komunikasi yang bersangkutan. Namun,

\footnotetext{
${ }^{5}$ Ley J. Moleong, Metodologi Penelitian Kualitatif, (Bandung: Rosdakarya, 2006), hal. 5

${ }^{6}$ Suharsimi Arikunto, Manajemen Penelitian, (Jakarta:Rineka Cipta,1990), hal. 321

${ }^{7}$ M. Burhan Bungin, Penelitian Kualitatif Komunikasi, Ekonomi, Kebijakan Publik, Dan Ilmu Sosial Lainnya, (Jakarta : Kencana, 2008), hal. 155

${ }^{8}$ Burhan Bungin, Analisis Data Penelitian Kualitatif Pemahaman Filosofis Dan Metodologis Ke Arah Penguasaan Modela Aplikasi, ( Jakarta:Rajawali Pers, 2008), hal.161.
} 
kalau objek penelitian berhubungan dengan pesan-pesan dalam suatu media, perlu dilakukan identifikasi pesan dan media yang mengantarkan pesan itu. ${ }^{9}$

\section{PERBINCANGAN ANALISIS MUTIARA TERPENDAM DALAM NOVEL BULAN TERBELAH DI LANGIT AMERIKA}

Novel ini menggunakan teori tentang nilai yang dikemukakan oleh milton rokeahbahwa nilai (value) adalah sesuatu yang berharga, yang dianggap bernilai, adil, baik, benar dan indah serta menjadi pedoman atau pegangan diri. Selain itu pendapat Milton Receach dan James Bank mengemukakan bahwa nilai adalah suatu tipe kepercayaan yang berada dalam ruang lingkup sistem kepercayaan, dimana seseorang harus bertindak atau menghindari suatu tindakan mengenai sesuatu yang pantas atau sesuatu yang tidak pantas dikerjakan, dimiliki dan dipercayai. Hal in sesuai dengan nilai-nilai pendidikan islam yang terdapat dalam novel bulan terbelah dilangit Amerika, nilai-nilai tersebut merupakan suatu tindakan yang baik dilakukan bagi setiap mausia dalam kehidupan sehari-hari.

Mutiara terpendam yang dimaksud penulis yang dilakukan dengan proses analisis untuk menjawab rumusan masalah mencakup tiga aspek nilai pendidikan Islam yang diperoleh dalam novel Bulan Terbelah di Langit Amerika yaitu nilai Aqidah, Syari'ah, dan Akhlak, yang secara rinci dijelaskan sebagai berikut:

\section{Nilai aqidah}

Aqidah secara bahasa (etimologi) yaitu sebagai ikatan, simpul dan perjanjian yang kuat dan kokoh. ${ }^{10}$ Ikatan dalam pengertian ini merujuk pada makna dasar bahwa manusia sejak azali telah terikat dengan suatu perjanjian yang kuat untuk menerima dan mengakui adanya sang pencipta yang mengaur dan menguasai dirinya, yaitu Allah swt. Selain itu, akidah juga mengandung cakupan keyakinan. Sistem kepercayaan atau akidah dibangun di atas enam dasar keimanan yang lazim disebut Rukun Iman yang meliputi keimanan kepada Allah, para malaikat, kitab-kitab, para rasul, hari kiamat, serta qadha dan qadar-Nya. Nilai Aqidah yang terdapat dalam di dalam novel Bulan Terbelah di Langit Amerika karya dapat dikelompokkan sebagai berikut:

\section{Iman kepada Allah}

Esensi dari iman kepada Allah adalah pengakuan tentang keesaan (tauhid)Nya. Tauhid berarti keyakinan tentang kebenaran keesaan Allah, tidak mempersekutukan-Nya dengan sesuatu apapun. Tauhid dalam hal ini ada tiga pemahaman yaitu tauhid uluhiyah, tauhid rububiyah, dan tauhid mulkiyah.

Iman kepada Allah dapat dilihat dari sikap yang meyakini bahwa kesulitan apapun yang dialami akan ada jalan keluarnya yang diberikan oleh Allah, Begitu pula sikap Hanum yang berprasangka baik terhadap Allah dalam menghadapi suatu persoalan tersebut dapat dilihat dari beberapa kutipan cerita sebagai berikut:

"Ya Allah, Maha pencari jalan keluar dari segalah macam masalahEngkau benarbenar telah menyelesaikan masalah hamba-Mu yangbernama Phippus Brown dengan cara tak terpikirkan"." ${ }^{11}$

\footnotetext{
${ }^{9}$ Ibid., hal. 164

${ }^{10}$ Rois Mahfud, Al-Islam: Pendidikan Agama Islam, (Jakarta: Penerbit Erlangga,2010), hal. 10

${ }^{11}$ Hanum Salsabiela Rais dan Rangga Almahendra, Bulan Terbelah Di Langit Amerika, (Jakarta: Gramedia Pustaka Utama, 2014), hal. 306
} 
"Sungguh tak bisa ku utarakan betapa Allah adalah penukarkebahagian dan kesedihan yang MahaAgung. Allah telah memanggil kembalihamba-Nyayang bernama Ibrahim Hussein kesisi-Nya, meninggalkan duka pada Azimadan Sarah, namun kini Tuhan jugamengembalikan hak mereka, diamengembalikan HyacinthCollinsworth ke pangkuan keduanya". ${ }^{12}$

Dari kutipan tersebut tergambar keimaman Hanum kepada Allah, Hanum meyakini suatu hal bahwa suatu kesukaran ataupun kebahagian semuanya Allah yang mengendalikan, Hanum memuji kebesaran Allah ketika mendengar pengakuan Philippus Brown akan suatu keindahan Islam yang mengajarkan suatu tolongmenolong dan sikap teladan dari sosok ibrahim Hussein, inilah keimananan yang melahirkan suatu sikap syukur kepada Allah terhadap dirinya, keyakinan bahwa Allah lah yang mempunyai sifat yang Maha Agung menjawab semua masalah tentunya masalah yang terjadi di Amerika akan anggapan-anggapan orang-orang Amerika tentang Islam terkait dengan tragedi 11 september 2001, melalui cerita dari Philippus Brown lah membuka mata Nyonya Collins serta orang-orang di Amerika bahwa tuduhannya terhadap Islam sebelumnya salah dan pada akhirnya nyonya collins merelakan Azima untuk memeluk Islam.

2. Iman kepada malaikat

Malaikat adalah makhluk ciptaan Allah SWT., yang bersumber dari cahaya; ia tidak dapat dilihat atau diindrai dengan pancaindera manusia-makhluk gaib. Namun demikian, ia tetap ada dan melaksanakan tugas-tugas yang diberikan oleh Allah SWT. Malaikat juga adalah makhluk ciptaan Allah SWT yang tidak pernah melanggar perintah Allah SWT. Dalam novel Bulan Terbelah di Langit Amerika ada beberapa kutipan cerita yang dapat menggambarkan sikap beriman kepada malaikat. Seperti dalam kutipan berikut ini:

"Ya Allah, Ya Tuhan, atas segala malaikat-malaikat di atas sana... Aku tidak benarbenar mengucapkannya. Aku tidak benar-benarmenginginkannya, mengapa Engkau kabulkan semua ini". ${ }^{13}$

Dari kutipan cerita tersebut terlihat bahwa memang Hanum percaya akan keberadaan malaikat-malaikat Allah itu ada yang diberi tugas oleh Allah dan melaksanakan tugas-tugas tersebut sebagaimana perintah-Nya. Kutipan tersebut menceritakan penyesalan Hanum tentang kata-katanya yang mengatakan bahwa dia berkeinginan pisah dengan Rangga di New York dan mencari narasumbernya sendiri sampai Allah mengabulkan hal tersebut, meskipun Hanum dalam keadaan terpuruk pada saat itu tersesat tak tau namun Hanum tidak berputus asa dan optimis mencari jalan keluar untuk masalahnya.

\section{Iman kepada kitab Allah}

"Selama "dia" tersimpan rapi dan aman, negeri besar ini akanterlindung dari apapun yang mengguncangnya, bisik sanubariku”. ${ }^{14}$

Dapat diinterpretasikan bahwa dari kutipan cerita tersebut menggambarkan atau bermakna kata "dia" dalam kalimat kutipan yang diucapkan Hanum di atas menunjukkan "dia" itu ditujukan sebagai salah satu kitab Allah yaitu Al-Qur'an, dengan demikian hal ini menyatakan bahwa Hanum sendiri berkeyakinan atau mempercayai kebesaran isi Al-Qur'an sebagai pedoman dan petunjuk hidup, begitu

\footnotetext{
${ }^{12}$ Ibid., hal. 318

${ }^{13}$ Ibid., hal.115

${ }^{14}$ Ibid., hal. 321
} 
pula orang non muslim yang juga ikut mempelajari Al-qur'an seperti Thomas Jafferson dan menyimpannya dengan baik.

"Dan tatkala mataku sibuk mencermati satu persatu benda yang ada dimeja sarah, hatiku bergetar saat pandangku menumbuk sebuah Al-Qur'anyang bersanding dengan Alkitab". ${ }^{15}$

Dari kutipan di atas dapat diinterpretasikan "hatiku bergetar", ketika melihat dua kitab Allah bersanding di atas meja, perasaan Hanum yang seperti ini menggambarkan suatu keimanan yang menggerakkan hatinya yang melahirkan ketaatannya kepada Allah, hati yang seperti itulah yang menuntun pada kebaikan dan memberi manfaat kepada kehidupan.

\section{Iman kepada rasul Allah}

Rasul yang berarti utusan mengandung makna manusia-manusia pilihan yang menerima wahyu dari Allah dan bertugas menyampaikan isi wahyu kepada tiap-tiap umatnya. ${ }^{16}$ Dalam beberapa kutipan cerita dalam novel Bulan Terbelah di Langit Amerika ini dapat menggambarkan suatu sikap Iman kepada Rosul:

"Ya, Nabi Muhammad Saw. Membelah bulan, mukjizat Allah yangdiberikan pada nabi penutup itu, selain mukjizat terbesarnya: Al-Qur'an.Semua muslim mengimaninya". ${ }^{17}$

"Sungguh tiba-tiba aku merasa seolah Ibrahim Hussein yang entah dimana di alam sana, turut menyaksikan keindahan manusia yang menyatukembali dalam keajaiban Tuhan, seperti bulan yang dibelah NabiMuhammad, lalu menyatu dengan Rima Ariadeus-nya". 18

Percaya kepada Nabi dan Rosul Allah merupakan rukun iman yang keempat dan setiap muslim wajib mempercayainya. Dapat diinterpretasikan melalui kutipan cerita di atas bahwa kita semua harus mengimani semua Nabi dan Rosul Allah meyakini bahwa mereka adalah orang yang terpilih untuk menerimah wahyu dari Allah, serta kita wajibkan untuk mengimani mukjizat-mukjizat yang mereka miliki, Islam mengajarkan suatu kedamaian dan Allah memilih Ibrahim Hussein untuk menunjukkan keindahan tersebut, mengajarkan kepada Philippus Brown akan nilai toleransi, menghormati dan menghargai agama lain serta membuka mata orang-orang Amerika tentang anggapan yang negatif yang membuat hubungan Islam dan Amerika sebelumnya menjadi pecah yang menimbulkan suatu permusuhan.

2. Iman kepada hari kiamat

Keyakinan atau kepercayaan akan adanya hari kiamat memberikan satu pelajaran bahwa semua yang bernyawa, terutama manusia akan mengalami kematian dan akan dibangkitkan kembali untuk mempertanggungjawabkan segala amal perbuatannya di dunia. ${ }^{19}$ Nilai iman terhadap Hari Akhir dapat digambarkan melalui kutipan cerita berikut ini:

" Hingga Akhirnya dia meninggal dunia aku bisikkan sesuatu yang lirihdi teligahnya: Nek Rumah sudah selesai direnovasi, nenek sudah bisa pulangselamanya". ${ }^{20}$

Hanum meyakini bahwa semua orang di dunia ini pada akhirnya akan kembali kepangkuan-Nya ketika ia dihadapkan dengan situasi neneknya yang sedang sakit dan harus dirawat di rumah sakit dan selalu ingin pulang dan sampai akhirnya neneknya meninggal, untuk itu semua kembali kepada setiap individu masing-masing

\footnotetext{
15 Ibid., hal. 160

${ }^{16}$ Rois Mahfud,Al-Islam: Pendidikan Agama Islam, (Jakarta : Penerbit Erlangga, 2010), hal. 18

${ }^{17}$ Hanum Salsabiela Rais, Bulan Terbelah..., hal. 314

${ }^{18}$ Ibid., hal. 321

${ }^{19}$ Rois Mahfud, Al-Islam: Pendidikan..., hal.19

${ }^{20}$ Hanum Salabiela Rais, Bulan Terbelah..., hal.175
} 
bagaimana ia menyiapkan bekal untuk kehidupannya di akhirat, kata "rumah" dalam kata tersebut yang Hanum ucapkan memberikan gambaran atau simbol akan adanya suatu tempat yang akan ditemui setelah meninggal dan kehidupan tersebut jauh lebih kekal dan abadi dari pada kehidupan di dunia.

3. Iman kepada qadha dan qadar

Iman kepada qadha dan qadar memberikan pemahaman bahwa kita wajib meyakini kemahabesaran dan kekuasaan Allah SWT sebagai satu-satunya dzat yang memiliki otoritas tunggal dalam menurunkan dan menentukan ketentuan apa saja bagi makhluk ciptaan-Nya. ${ }^{21}$

"Aku katakan padanya, sejak awal aku tahu Tuhan akan mempertemukanku dengan narasumber terpilih. Tapi tentulah cara Tuhansangat unik. Aku tak percaya dengan ketidak acuhanku terhadap semuanama-nama nasumber hasil riset gertrud tenyata membawaku pada takdiryang bersuka cita". ${ }^{22}$

Kebahagian Hanum terhadap ketetapan yang diberikan Allah, mengenai dia dipertemukannya dengan Azima narasumbernya melalui cara tak terduga, Azima yang menolongnya ketika dalam ketersesatan di New York, dan sesuatu menjadi keterkejutan Hanum bahwa nama Azima sudah ada sejak awal dalam nama-nama narasumber yang disarankan oleh Gertrud, sikap Hanum yang menggambarkan kepercayaannya terhadap semua keadaan yang sudah dialami merupakan kehendak Allah bahwa bagaimanapun Hanum menghindari nama-nama narasumber yang Gertrud sarankan namun takdir berkata berbeda bahwa narasumber yang ditemui Hanum masih merupakan narasumber yang berada dalam riset Gertrud, hal tersebut merupakan bentuk keyakinan Hanum terhadap takdir yang sudah gariskan oleh Allah, kita sebagai seorang muslim wajib mengimani takdir Allah.

\section{Nilai Syari'ah}

Ibadah diartikan secara sederhana sebagai persembahan, yaitu sembahan manusia kepada Allah SWT sebagai wujud penghambaan diri kepada Allah SWT. Perbuatan apapaun yang dilakukan seorang muslim selama itu baik dan diniatkan hanya karena Allah SWT, maka perbuatan tersebut bernilai ibadah di sisi Allah SWT. $^{23}$

\section{Membaca Al-Qur'an}

"Persoalan Klise, pikirku. Masjid di Wina tempat aku dan Hanum biasamengajarkan Al-Qur'an juga dirundung masalah yang sama. Tak sanggupmembayar tunggakan sewa yang melejit harganya". ${ }^{24}$

Dapat diinterpretasikan dari kutipan tersebut Hanum dan Rangga mengajarkan membaca Al-Qur'an ketika mereka berada di wina Mengajarkan Al-Qur'an adalah salah satu bentuk Ibadah kita kepada Allah dan termasuk kedalam amalan yang nyata, suatu prilaku yang mulia karna mampu menempatkan diri agar dapat bermanfaat bagi orang lain dengan membantu mereka yang membutuhkan dalam mempelajari AlQur'an hal tersebut merupakan sebaik baiknya manusia.

\footnotetext{
${ }^{21}$ Rois Mahfud, Al-Islam: Pendidikan..., hal.21

${ }^{22}$ Hanum Salabiela Rais, Bulan Terbelah ..., hal. 150

${ }^{23}$ Rois Mahfud, Al-Islam: Pendidikan..., hal.23

${ }^{24}$ Hanum Salsabiela Rais, Bulan Terbelah..., hal. 76
} 


\section{Sedekah}

Dalam cerita ini juga terdapat pesan mengenai suatu pemberian yang dengan Ikhlas secara suka rela tanpa dibatasi oleh waktu yaitu suatu cerminan mengenai konsep sedekah tidak akan mengurangi harta yang kita miliki meskipun dalam suatu bisnis dapat digambarkan melalui kutipan sebagai berikut:

"Tapi aku meyakini agamaku telah sebenar-sebenarnya mengajarkan konsep memberi bagi mereka yang membutuhkan merupakan aksimembersihkan diri sendiri, keluarga, dan kehidupan. Namun dalam hal inimemberi justru menambah. Asalkan tangan pemberi tak berharapmendapatkan balasan, bahkan terimah kasih kasih sekalipun. "25

\section{Berdzikir kepada Allah}

"Tersengguk sengguklah perempuan penyelamatku ini. Seketika akuterpekut, bertasbih atas nama-Nya dalam kalbu ku. Ku tarik Azima dalamdekapan seperti tadi malam se erat-eratnya". ${ }^{26}$

Dapat diinterpretasikan dalam kutipan ini mencerminkan tinggi sikap persaudaraan yang dimiliki Hanum, ketika Hanum ikut peduli dengan kesedihankesedihan Azima dan melahirkan sikap positif dari Hanum dengan berdzikir menyebut Asma Allah di dalam hatinya.

\section{Nilai akhlak}

Akhlak berasal dari bahasa arab yang merupkan benuk jamak kata khuluq atau al-khulq yang berarti perangai, budi pekerti, dan tingkah laku. ${ }^{27}$ Akhlak merupakan seperangkat nilai keagamaan yang harusdirealisasikan dalam kehidupan sehari-hari dan merupakan keharusan,siap pakai, dan bersumber dari wahyu ilahi.

Adapun sikap yang berkaitan dengan nilai Akhlaq yang dapat digambarkan dalam novel Bulan Terbelah di Langit Amerika adalah sebagai berikut:

a. Sabar

"Sebagai karyawan, aku mencoba patuh memenuhi permintaannya,walaupun kadang-kadang sering membuatku tersedak. Hatiku sendiri sudahlulu padanya. Sejak dia merasa cocok dengan tulisan-tulisanku tentangprofil tokoh, Gertrud tak hanya menjadikanku karyawan, tapi jugasahabatnya". ${ }^{28}$

Dari kutipan cerita di atas dapat diinterpretasikan bahwa Hanum mencoba sabar menghadapi perintah-perintah Gertrud ketika ditugaskan membuat berita meskipun hal tersebut sering kali menyulitkan Hanum, Hanum dengan sabar mengikuti hal tersebut karena ia mempunyai misi untuk menjadi agen muslim yang baik dimana pun ia berada, dan ia ingin mengubah pemikiran orang-orang lokal tentang hal negatif akibat media barat. Salah satu tugas dari Gertrud adalah memerintahkan Hanum untuk membuat artikel akankah dunia lebih baik tanpa Islam? Disinilah Hanum merasa harus berjuang berperang melalui intelektualnya agar dapat mengubah pemikiran orangorang barat tentang Islam.

Sikap sabar Hanum juga dapat di gambarkan dalam kutipan cerita berikut ini:

"Aku mengecek dompetku. Hanya ada uang US\$15 ditangan. Semuadokumen, paspor, naskah, dan data narasumber hingga baju ganti adadalam koper yang

\footnotetext{
${ }^{25}$ Ibid., hal. 244

${ }^{26}$ Ibid., hal. 240

${ }^{27}$ Mohammad Daud Ali, Pendidikan Agama Islam, (Jakarta: PT Raja Grafindo, 2004), ed. 1, cet. 5 , hal.346

${ }^{28}$ Hanum Salsabiela Rais, Bulan Terbelah..., hal. 36
} 
dibawah Rangga, Aku memandangi telepon gengam kesayanganku yang bentuknya kini tak keruan. Kenanganku bersamatelepongengam ini seakan ikut terinjak-injak". ${ }^{29}$

Dari kutipan cerita di atas menggambarkan sikap sabar Hanum dalam menerima cobaan yang harus diterima olehnya ketika terjebak dalam situasi yang tidak menyenangkan seperti harus terjebak dalam kerusuhan, terkena lemparan botol pada saat kericuhan, serta telepon genggam serta alat rekamnya yang mengalami kerusakan.

\section{b. Bekerja keras}

Kegigihan Hanum setelah berusaha mewawancarai Michael Jhones yang pada Awal tidak perdulikan Jhones serta situasi yang menyebabkan Hanum terjebak di dalam kericuhan demonstrasi tak menghentikan Hanum untuk berjuang dan bekerja keras untuk mencari narasumbernya dan keyakinan akan hasil kerja kerasnya akan berhasil.

"Kata orang, keterbatasan membuat orang kreatif, keterbatasanmembuat orang terpecut melakukan apapun yang di jalani denganmaksimal. Keterbatasan tak ubahnya situasi yang dibuat Tuhan untukmembuat kita lebih berjuang. Jika berhasil melewati keterbatasan itu, buahperjuangan yang akan kita dapatkan akan lebih berkesan." 30

\section{c. Optimis}

Suatu keberhasilan tentunya juga dipengaruhi oleh cara berpikir seseorang, dengan demikian suatu sikap yang optimis sangat diperlukan dalam setiap individu hal ini tercermin dari sikap Hanum yang digambarkan dari kutipan-kutipan dalam novel Bulan Terbelah di langit Amerika sebagai berikut:

"Mengaliri situasi dengan energi positif adalah cara terbaik dalamkondisi yang tidak pasti seperti ini. Ku tatah kata-kata pasti bisa, pastiketemu dalam pikiran, aku menepuk-nepuk tulang belikat di dada untukmelontarkan semangat. Gagal coba lagi, gagal coba lagi dan seterusnyahingga Tuhan yakin kesungguhan hati ini untuk bertemu dengan narasumbersejati. Adalah sebuah keindahan".31

Sebuah harapan Hanum yang begitu besar dalam mencari narasumber dan tentunya diiringi dengan kerja keras itulah yang dinamakan sikap optimis yang sebenarnya, hasil yang baik dari suatu hal tidak akan kita dapatkan jika kita hanya berpikir optimis namun tidak diiringi usaha, misalkan dalam suatu kasus perlombaan kita yakin, optimis kita menang namun tak ada usaha yang kita lakukan maka itu akan percuma hal merupakan sikap yang kurang tepat, dari kutipan di atas memberi contoh sikap optimis yang seharusnya yaitu diiringi dengan usaha, bukan hanya berdiam diri saja.

\section{d. Bersyukur}

Bersyukur adalah suatu perbuatan yang bertujuan untuk berterimakasih atas segala limpahan nikmat yang telah diberikan oleh Allah SWT berikan. Suatu sikap syukur termasuk sikap terpuji dan mulia. Dalam kutipan cerita dapat digambarkan sikap Hanum yang mencerminkan sikap Syukur :

"Terkadang kita memang tak adil pada hidup kita sendiri. Tatkala takada pilihan kita menggerutu. Padahal tuhan tak memberi pilihan lain karenamenunjukkan itulah satusatunya pilihan terbaik hidup kita", 32

Kutipan tersebut bermakna bahwa sering kali kita bersikap tidak bersyukur atas suatu keadaan tatkalah kita tidak menyukai hal tersebut atau pada saat kita

\footnotetext{
${ }^{29}$ Ibid., hal.110

${ }^{30}$ Ibid., hal.109

${ }^{31}$ Ibid., hal. 88

${ }^{32}$ Ibid., hal. 183
} 
dihadapkan pada suatu masalah, suatu sikap yang sering salah muncul adalah menggerutuh terhadap masalah tersebut, padahal kita tidak menyadari bahwa setiap masalah yang kita hadapi kita dapat mengambil pelajaran untuk melangkah kedepannya, bahwa sebenarnya itulah pilihan terbaik dari Allah untuk kita jalani.

\section{e. Berbakti kepada orang tua}

Berbakti kepada orang tua merupakan ahklak terpuji, berbakti kepada orang tua mempunyai makna kita harus taat akan perintah orang tua, namun dalam batasan tidak melanggar apa yang diperintahkan oleh Allah, meskipun seorang anak sudah berkeluarga dia tetap berkewajiban berbakti kepada orangtuanya. Ada beberapa kutipan dari novel Bulan terbelah di Langit Amerika yang menggambarkan sikap bakti kepada orangtua khususnya ibu sebagai berikut:

"Azima,.. Maaf bolehkah aku memanggilmu Azima?"

"Tentu Hanum. Tapi jangan di depan ibuku nanti. Dia tidakmenyukainya. "33

Dari kutipan tersebut dapat diinterpretasikan bahwa menggambarkan sikap Azima yang baik terhadap ibunya meskipun mereka berbeda agama namun Azima tetap menghormati ibunya serta menghargai perasaannya, hal itu dibuktikan dengan sikap Azima yang tak ingin menyakiti hati ibunya bahwa dia seorang muslim. Kita sebagai seorang muslim diwajibkan menaati kedua orang tua khususnya ibu kita seperti dalam hadits nabi:

Dari Abu Hurairah radhiyallaahu 'anhu, belia berkata, "Seseorang datang kepada Rasulullah shalallahu 'alaihi wasallam dan berkata, 'Wahai Rasulullah, kepada siapakah aku harus berbakti pertama kali?' Nabi shalallaahu 'alaihi wasallam menjawab, 'Ibumu!' Dan orang tersebut kembali bertanya, 'Kemudian siapa lagi?' Nabi shalallaahu 'alaihi wasallam menjawab, 'Ibumu!' Orang tersebut bertanya kembali, 'Kemudian siapa lagi?' Beliau menjawab, 'Ibumu.' Orang tersebut bertanya kembali, 'Kemudian siapa lagi,' Nabi shalallahu 'alaihi wasallam menjawab, 'Kemudian ayahmu.'” (HR. Bukhari no. 5971) ${ }^{34}$

\section{Kesimpulan}

Berdasarkan hasil interpretasi mendalam menjawab dari rumusan masalah hasil skripsi penulis dalam mengkaji pembahasan sesuai dengan rumusan masalah dapat disimpulkan, sebagai berikut: mutiara terpendam dalam novel Bulan Terbelah di Langit Amerika terbagi menjadi nilai Aqidah, nilai Syariah, dan nilai Akhlak. Nilainilai tersebut terdapat kategori lagi sebagai berikut: a. Nilai Aqidah : nilai aqidah yang terdapat dalam cerita tersebut meliputi Iman kepada Allah, Iman kepada Malaikat, Iman kepada kitab-kitab Allah, Iman kepada Nabi dan Rosul, Iman kepada hari Akhir, dan Iman kepada Qada' dan Qadar. b. Nilai Syariah: meliputi: membaca Al-Qur'an dan berdzikir kepada Allah. c. Nilai Akhlak: meliputi: nilai Sabar, Optimis dan Bersyukur, Berbakti kepada orangtua.

\footnotetext{
${ }^{33}$ Ibid., hal.155

${ }^{34}$ https://muslimah.or.id/1861-ibumu-kemudian-ibumu-kemudianibumu.html, diakses,pada tanggal 21 mei 2019, pukul 11:32 wib
} 


\section{Daftar Pustaka}

Abdullah Nashih 'Ulwan. 2016. Pendidikan Anak Dalam Islam. Jawa Tengah: Insan Kamil.

Abdurrahmat Fathoni. 2006. Metodologi Penelitian \& Teknik Penyusunan Skripsi. Jakarta :Rineka Cipta.

Burhan Bungin. 2008. Analisis Data Penelitian Kualitatif Pemahaman Filosofis Dan Metodologis Ke Arah Penguasaan Modela Aplikasi. Jakarta:Rajawali Pers.

Burhan Bungin. 2008. Penelitian Kualitatif Komunikasi, Ekonomi, Kebijakan Publik, Dan Ilmu Sosial Lainnya. Jakarta : Kencana.

Hanum Salsabiela Rais dan Rangga Almahendra. 2014.Bulan Terbelah Di Langit Amerika. Jakarta: Gramedia Pustaka Utama.

Ley J. Moleong. 2006. Metodologi Penelitian Kualitatif. Bandung: Rosdakarya

Mohammad Daud Ali. 2004. Pendidikan Agama Islam. Jakarta: PT Raja Grafindo.

Nurul Zuriah. 2007. Metodologi Penelitian Sosial Dan Pendidikan Teori Dan Aplikasi,. Jakarta: Bumi Aksara.

Rois Mahfud. 2010. Al-Islam: Pendidikan Agama Islam. Jakarta: Penerbit Erlangga.

Suharsimi Arikunto. 1990. Manajemen Penelitian. Jakarta:Rineka Cipta.

Sumber: https://islamhariini.com/keutamaan-belajar-dan-mengajarkan-alquran/ | Website Islam Hari Ini diakses pada tanggal 20 mei 2019, pukul 19:30 $\underline{\text { wib }}$

https://muslimah.or.id/1861-ibumu-kemudian-ibumu-kemudianibumu.html, diakses,pada tanggal 21 mei 2019, pukul 11:32 wib

https://www.suara.com/lifestyle/2018/02/21/173000/miris-minat-baca-masyarakatindonesia-hanya-001-persen, diakses pada tanggal 26 Desember 2018, pukul $\underline{14.05 \mathrm{WIB} .}$

http://edukasi.kompas.com/read/2016/08/29/07175131/minat.baca.indonesia.ada.di.ur utan.ke-60.dunia diakses pada tanggal 26 Desember 2018, pukul 14.05 WIB. 